\title{
FLIGHT ACTIVITY OF Melipona asilvai MOURE (HYMENOPTERA: APIDAE)
}

\author{
SOUZA, B. A. ${ }^{1}$, CARVALHO, C. A. L. ${ }^{2}$ and ALVES, R. M. O. ${ }^{3}$ \\ ${ }^{1}$ Escola Superior de Agricultura "Luiz de Queiroz", Departamento de Entomologia, Fitopatologia e Zoologia Agrícola, \\ Universidade de São Paulo, Av. Pádua Dias, 11, C. P. 09, CEP 13418-900, Piracicaba, SP, Brasil \\ ${ }^{2}$ Escola de Agronomia, Departamento de Fitotecnia, Universidade Federal da Bahia, \\ CEP 44380-000, Cruz das Almas, BA, Brasil \\ ${ }^{3}$ Escola Agrotécnica Federal de Catu, Catu, BA, Brasil \\ Correspondence to: Bruno de Almeida Souza, Escola Superior de Agricultura "Luiz de Queiroz", \\ Departamento de Entomologia, Fitopatologia e Zoologia Agrícola, Universidade de São Paulo, \\ Av. Pádua Dias, 11, C. P. 09, CEP 13418-900, Piracicaba, SP, Brazil, e-mail: bsouza@esalq.usp.br \\ Received August 9, 2004 - Accepted December 22, 2004 - Distributed May 31, 2006
}

(With 2 figures)

\begin{abstract}
Many stingless bee species are specific to their areas of occurrence. Even when adapted to their local climate and flora conditions, they are subject to modifications in the environment, directly influencing flight activity. The aim of this work is to obtain information about the flight activity of the stingless bee Melipona asilvai Moure, thus contributing to the knowledge of this species. The flow of bees entering and leaving the colony was evaluated, and the type of transported material was identified. This information was correlated with climatic data collected at the time of observations, performed between June 2002 and March 2003. It can be proved that temperature was the factor with the greatest influence on the external activity of this species, showing a significant positive correlation with the entry of bees into the colony and pollen collection. Mud collecting showed a significant positive correlation with a humidity increase. Flight activity began at a temperature of $21.0{ }^{\circ} \mathrm{C}$ and humidity of $84.5 \%$, peaking at $27.4{ }^{\circ} \mathrm{C}$ and $60.6 \%$ $\mathrm{RH}$, respectively.
\end{abstract}

Keywords: stingless bee, Meliponina, meliponiculture.

\section{RESUMO}

\section{Atividade de vôo de Melipona asilvai Moure (Hymenoptera: Apidae)}

Muitas espécies de meliponíneos são específicas de suas regiões de ocorrência. Mesmo sendo adaptadas às condições locais de clima e flora, estão sujeitas às modificações do ambiente externo, influenciando diretamente a sua atividade de vôo. Este trabalho teve como objetivo obter informações sobre a atividade de vôo de Melipona asilvai Moure, contribuindo para o conhecimento desta espécie. Foi avaliado o fluxo de abelhas, entrando e saindo da colônia, e a identificação do tipo de material transportado. Estas informações foram correlacionadas com dados climáticos coletados no momento das observações, realizadas entre junho de 2002 e março de 2003. A temperatura foi o fator de maior influência sobre a atividade de vôo desta espécie, apresentando correlação positiva significativa com a entrada de abelhas na colônia e com a coleta de pólen. A coleta de barro apresentou correlação positiva significativa com o aumento da umidade. A atividade de vôo foi iniciada à temperatura de $21,0{ }^{\circ} \mathrm{C}$ e umidade de $84,5 \%$, apresentando pico com $27,4{ }^{\circ} \mathrm{C}$ e $60,6 \%$, respectivamente.

Palavras-chave: abelha sem ferrão, Meliponina, meliponicultura. 


\section{INTRODUCTION}

Social insects, such as stingless bees, respond to variations in external conditions by adjusting to the colony's internal environment. These alterations directly influence internal and external activities, such as the construction of cells and food pots, and foraging (Kerr, 1996; Biesmeijer et al., 1999; Hilário et al., 2001).

The external activity of bees is associated with different types of behavior, such as collecting material used to build the colony, hygiene, and food collecting. Thus, the movement of field bees leaving to collect nectar, pollen, resin, and mud, and to transport debris out of the colony can be commonly observed (Roubik, 1989; Kerr et al., 1996; Carvalho et al., 1999).

Information on the flight activity of bees is important, because it provides data that can be used in pollinator management programs, studies on the biology of bees, genetic potential of the colony, and foraging behavior, among others (Iwama, 1977; Hilário et al., 2000).

The foraging behavior of stingless bee species may vary according to the species strategies, interspecific competition, floral preference, and plant phenology (Ramalho et al., 1989; Bruening, 1990; Hilário et al., 2001).

There have been accounts concerning the external activity of some species of the genus Melipona, such as $M$. beecheii (Biesmeijer et al., 1999), M. bicolor (Hilário et al., 2000), M. compressipes (Kerr, 1996), M. quadrifasciata (Guibu et al., 1988), M. subnitida (Bruening, 1990), and M. scutellaris (Kerr et al., 1996).

M. asilvai Moure is one of the meliponine species commonly found in the semi-arid region of Bahia (Carvalho, 1999; Zanella, 2000), and is considered a "lazy" species by woodsmen ("mateiros"), due to the reduced external movement that is observed in its colonies.

The aim of this work is to obtain information regarding the flight activity of $M$. asilvai, therefore contributing to increase the knowledge about this species.

\section{MATERIAL AND METHODS}

The colonies used in this study came from the municipalities of Itaberaba and Tucano, in the State of Bahia, and were installed at the meliponine rearing facility (meliponary) of Pedra Branca, in the municipality of Santa Terezinha-BA, where the occurrence of this species has also been recorded.

In order to evaluate the number of bees in flight activity, observations of the number of individuals that entered and left five colonies previously selected by drawing lots were made every two weeks during the interval from $5 \mathrm{~h}$ am to $7 \mathrm{~h} \mathrm{pm}$ from June 2002 to March 2003.

A total of 1,400 observations were made, and the number of bees in flight activity was determined during a maximum time of $10 \mathrm{~min} /$ colony/hour or by an actual count of 15 individuals/colony/10 min, according to methodology adapted from Carvalho \& Marchini (1999).

Temperature in the environment and relative humidity data were obtained by means of a drybulb/wet-bulb thermometer, and by a maximum/ minimum thermometer, installed at the meliponary site.

Information about the material transported by the bees was additionally obtained by direct observation and by occasionally collecting bees.

Identification of resin, mud and pollen loads was made based on the characteristics shown by these materials (resin = shiny mass; mud $=$ irregular mass with a granular aspect; pollen $=$ dull, defined mass). Counts of bees carrying debris loads out of the colony were based on the number of bees leaving with this type of material in their mandibles.

Since it was not possible to identify nectar transport, we simply counted bees entering the colony without an apparent load. Thus, the data obtained were correlated with the SAEG program (Sistema para Análises Estatísticas - System of Statistical Analyses) using Spearman's nonparametric test at the 5\% and $1 \%$ significance levels.

\section{RESULTS AND DISCUSSION}

The flight activity of M. asilvai varied over the months (Fig. 1), and the greatest traffic of entries and exits of bees was observed in January 2003. In June and July, 2002, rains with variable intensity occurred throughout the data collection days, and the lowest activity of bees was observed in June.

The greatest flight activity in September, January and March, which was also when the area was most in bloom, suggests that $M$. asilvai colonies 

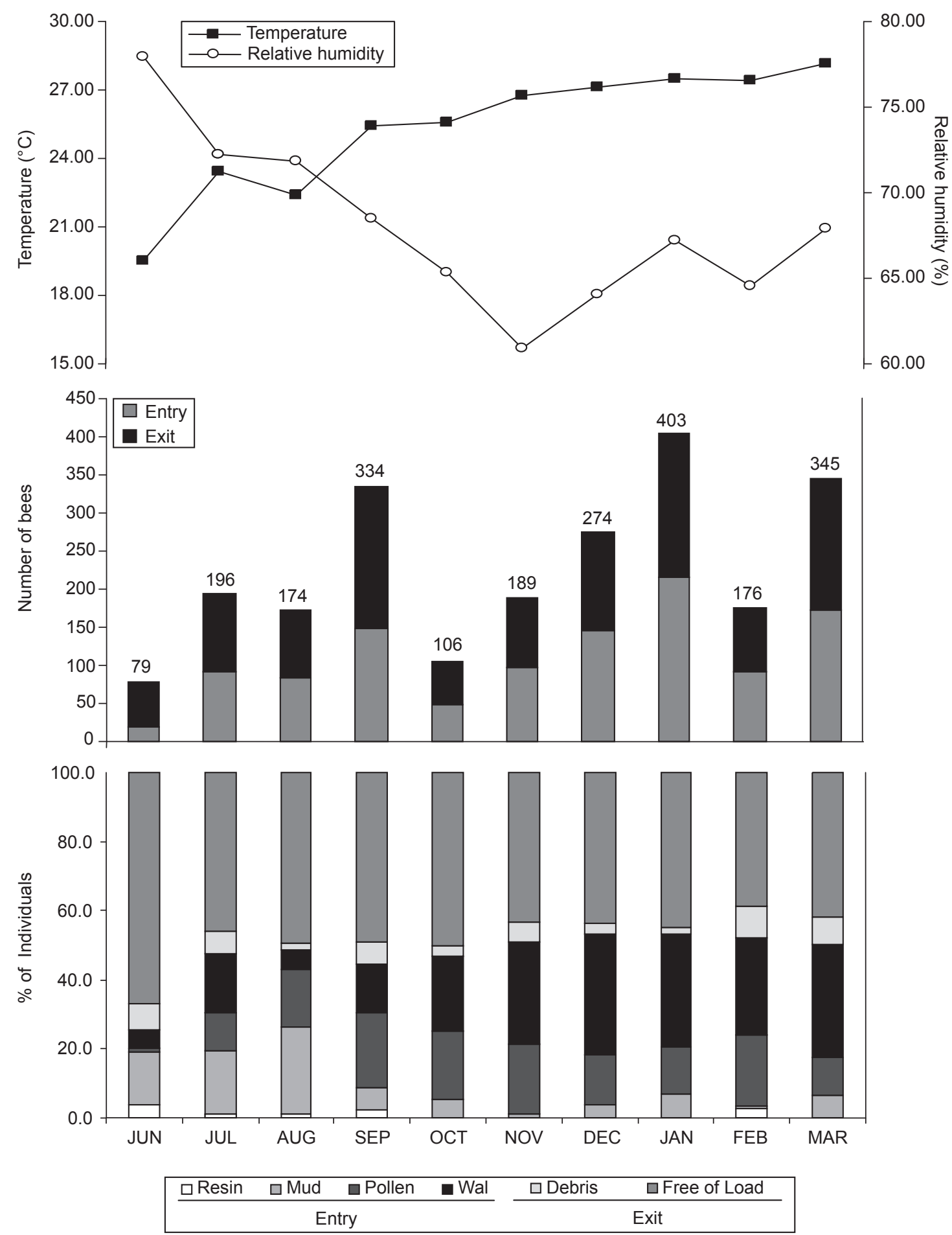

Fig. 1 - Variation in temperature and relative humidity in Santa Terezinha-BA, monthly traffic of Melipona asilvai foragers, and flight activity and transported material distribution: June/2002 to March/2003 (WAL = bee without apparent load). 
have a seasonal activity with trophic resources available and that colonies are more developed.

No significant correlation between relative humidity and entry and exit of bees from the colony was observed. Temperature, however, showed a positive correlation $(\mathrm{p}<0.05)$ with bee entry traffic (Table 1).

Roubik (1989) stated that meteorological factors, the insect's physiology, and mechanisms of secretion, and the quality of nectar produced by plants influence the external activity of bees.

Some authors have reported the influence of climatic factors on the flight activity of meliponines. Temperature, light intensity, and relative humidity were the factors that most influenced the external activity of Tetragonisca angustula (Iwama, 1977). For Plebeia pugnax, Hilário et al. (2001) observed flight activity at temperatures between $22{ }^{\circ} \mathrm{C}$ and $34{ }^{\circ} \mathrm{C}$ and at all relative humidity readings, which ranged from $30 \%$ to $100 \%$. The same authors did not observe an influence of light intensity on the activity of $P$. pugnax.

When the external activity of $M$. asilvai is analyzed with regards to collecting food and nest building materials, one can observe that the entry and exit activities of bees in the colony showed high correlation with pollen collection $(\mathrm{p}<0.01)$ and entry of bees without apparent load ( $\mathrm{p}<0.01$ for bee entry and $p<0.05$ for exit).

Debris transport also showed a positive correlation with the entry and exit traffic of bees from the colony, with the entry of bees without apparent loads, and with entry of bees carrying pollen loads ( $p<0.05$ for all). Greater food availability suggests greater egg-laying stimulation for the queen and greater colony growth, directly influencing the amount of debris produced.

There was no significant correlation between resin collection and the other parameters analyzed in this study.

With regards to mud, a greater collecting activity was observed in the months with higher humidity, and a positive correlation $(\mathrm{p}<0.05)$ was observed for this climatic factor.

M. asilvai collects large amounts of mud to be used when building the colony. The absence of moist mud due to high temperatures and low humidity can cause this bee to collect feces of animals as replacement material for mud, implying greater care concerning the management of this species by those willing to raise it.

Collection of pollen by M. asilvai increased starting in August 2002, without a great variation until March, 2003, which is a major period of blooming for the species in the region, suggesting the occurrence of greater availability of nectar and pollen for the bees. The entry of bees without apparent load increased in October 2002, and remained steady until March 2003, a period in which the temperature was higher.

The number of bees entering the colony without an apparent load showed a positive

TABLE 1

Coefficient of correlation (Spearman's non-parametric test) between conditions in the environment and external activity of Melipona asilvai workers. Santa Terezinha-BA: June 2002 to March 2003.

\begin{tabular}{|l|c|c|c|c|c|c|c|c|}
\hline & MUD & DEB & POL & WAL & ENT & EXI & RHD & TEM \\
\hline RES & $-0.10 \mathrm{~ns}$ & $0.25 \mathrm{~ns}$ & $-0.04 \mathrm{~ns}$ & $-0.43 \mathrm{~ns}$ & $-0.29 \mathrm{~ns}$ & $-0.09 \mathrm{~ns}$ & $0.40 \mathrm{~ns}$ & $-0.50 \mathrm{~ns}$ \\
\hline MUD & - & $-0.13 \mathrm{~ns}$ & $0.01 \mathrm{~ns}$ & $-0.10 \mathrm{~ns}$ & $0.23 \mathrm{~ns}$ & $0.47 \mathrm{~ns}$ & $0.65 *$ & $-0.25 \mathrm{~ns}$ \\
\hline DEB & - & - & $0.55 *$ & $0.58 *$ & $0.63 *$ & $0.56 *$ & $-0.12 \mathrm{~ns}$ & $0.51 \mathrm{~ns}$ \\
\hline POL & - & - & - & $0.77 * *$ & $0.86 * *$ & $0.80 * *$ & $-0.43 \mathrm{~ns}$ & $0.61 *$ \\
\hline WAL & - & - & - & - & $0.90 * *$ & $0.70 *$ & $-0.60 *$ & $0.92 * *$ \\
\hline ENT & - & - & - & - & - & $0.93 * *$ & $-0.28 \mathrm{~ns}$ & $0.72 *$ \\
\hline EXI & - & - & - & - & - & - & $0.03 \mathrm{~ns}$ & $0.43 \mathrm{~ns}$ \\
\hline RHD & - & - & - & - & - & - & - & $-0.70 *$ \\
\hline
\end{tabular}

*, **: significant at $5 \%$ and $1 \%$ probability, respectively, by Fisher's " $\mathrm{z}$ " test; $\mathrm{ns}=$ non significant. RES = resin load; MUD = mud load; DEB = debris load; POL = pollen load; WAL = entry of bees without apparent load; ENT = entry of bees in the colony; EXI = exit of bees from the colony; RHD = relative humidity; TEM = temperature in the environment. 
correlation with the temperature $(\mathrm{p}<0.01)$ and a negative correlation with humidity $(\mathrm{p}<0.05)$. Pollen collection also showed a positive correlation with the temperature $(\mathrm{p}<0.05)$. Entries of bees without an apparent load and carrying a pollen load showed a positive correlation among themselves $(\mathrm{p}<0.01)$.

Lorenzon et al. (2003) observed that the greatest concentration of blooms in the southern region of the State of Piauí occurred during the rainy season ( $84 \%$ of the plant species were visited by bees); the greatest activity of bees on flowers was also observed in this period. During the dry season, the foraging activity of bees decreased, and it was observed that meliponines and Apis mellifera exploited about $16 \%$ of the flowering plants.

With regards to flight activity throughout the day, it was observed that it effectively started at $6 \mathrm{~h}$ am, and activity occurred sporadically before that time interval. The external activity of the colony extended through the $6 \mathrm{~h} \mathrm{pm}$ interval, and no movement was observed after that time (Fig. 2). The beginning of the effective flight activity of M. asilvai took place at mean temperature values of $21.0^{\circ} \mathrm{C}$ and mean relative humidity values of $84.5 \%$ ( $6 \mathrm{~h} 1 \mathrm{~min}-7 \mathrm{~h} \mathrm{am}$ ), and peak activity was observed in the interval from $1 \mathrm{~h} 1 \mathrm{~min}-2 \mathrm{~h} \mathrm{pm}$, when the temperature was $27.4{ }^{\circ} \mathrm{C}$ and humidity was $60.6 \%$. The bees' external activity ended at $6 \mathrm{~h} \mathrm{pm}$ at a temperature of $26.0^{\circ} \mathrm{C}$ and humidity of $61.0 \%$.

The interruption of the external activity of $M$. asilvai at $6 \mathrm{~h} \mathrm{pm}$ was observed even when temperature and humidity allowed flight activity conditions. Light intensity and trophic resources availability at that time could have influenced the activity of those bees.

A similar situation was observed by Iwama (1977) in T. angustula colonies, where the field activity ended at sundown with higher temperatures than those at which the external activity had begun. The beginning of flight activity in that species occurred between $17{ }^{\circ} \mathrm{C}$ and $24{ }^{\circ} \mathrm{C}$ and ended between $18{ }^{\circ} \mathrm{C}$ and $23^{\circ} \mathrm{C}$.

M. bicolor bicolor showed maximum flight activity at $18{ }^{\circ} \mathrm{C}$ and between $80 \%$ and $89 \%$ relative humidity; the minimum temperature for external activity was $11^{\circ} \mathrm{C}$ (Hilário et al., 2001).

According to Guibu et al. (1988), the species M. quadrifasciata quadrifasciata shows an increase in external traffic especially at temperatures between $14{ }^{\circ} \mathrm{C}$ and $16{ }^{\circ} \mathrm{C}$ and at high relative humidity $(80 \%$ to $90 \%$ ) with greatest activity between $8 \mathrm{~h}$ am and $9 \mathrm{~h}$ am.

Mouga (1984) observed that for Paratrigona subnuda the greatest flight activity occurs between temperatures of $24{ }^{\circ} \mathrm{C}$ and $25^{\circ} \mathrm{C}$, and at relative humidity values from $40 \%$ to $60 \%$.

M. subnitida showed intense traffic in the period between $2 \mathrm{~h} \mathrm{pm}$ and $5 \mathrm{~h} \mathrm{pm}$, possibly to exploit a certain flower species that would secrete nectar at that time (Bruening, 1990), while $M$. beecheii increased its foraging activity between $7 \mathrm{~h} 30 \mathrm{~min}$ am and $8 \mathrm{~h} 30 \mathrm{~min}$ am (Biesmeijer et al., 1999).

Pierrot \& Schlindwein (2003) observed that more than $90 \%$ of the pollen collection flights of M. scutellaris were made between $5 \mathrm{~h}$ am and $9 \mathrm{~h}$ am. There was a gradual reduction in pollen collection throughout the day. In contrast, the nectar foraging flights showed a more uniform distribution during the day.

Hilário et al. (2001) and Ramalho et al. (1989) observed that different bee species inhabiting the same region can have different external activity times during the day, in addition to exploring different floral resources; this fact is related to different foraging strategies and floral preferences avoiding possible interspecific competition.

Food availability can undergo variations related to environmental changes and daily or seasonal cycles influence both the internal and external activities of bees (Hilário et al., 2000).

Pedro \& Camargo (1991) observed that $A$. mellifera collects resources in a more uniform manner during the day, and peaks can be observed earlier in the morning ( $6 \mathrm{~h}$ and $8 \mathrm{~h} \mathrm{am}$ ) and later in the afternoon between $4 \mathrm{~h} \mathrm{pm}$ and $6 \mathrm{~h} \mathrm{pm}$. The remaining species observed by those authors were more abundant between $10 \mathrm{~h}$ am and $2 \mathrm{~h} \mathrm{pm}$.

An increase in the flight activity of $M$. asilvai could be observed as temperature in the environment tended to increase and relative humidity tended to decrease with greater traffic from $10 \mathrm{~h}$ am to $3 \mathrm{~h} \mathrm{pm}$.

Roubik (1989) stated that some foraging patterns do exist with a pollen-collecting peak in the early morning and a nectar-collecting peak in the late morning. According to this author, a second collecting peak of these trophic resources 

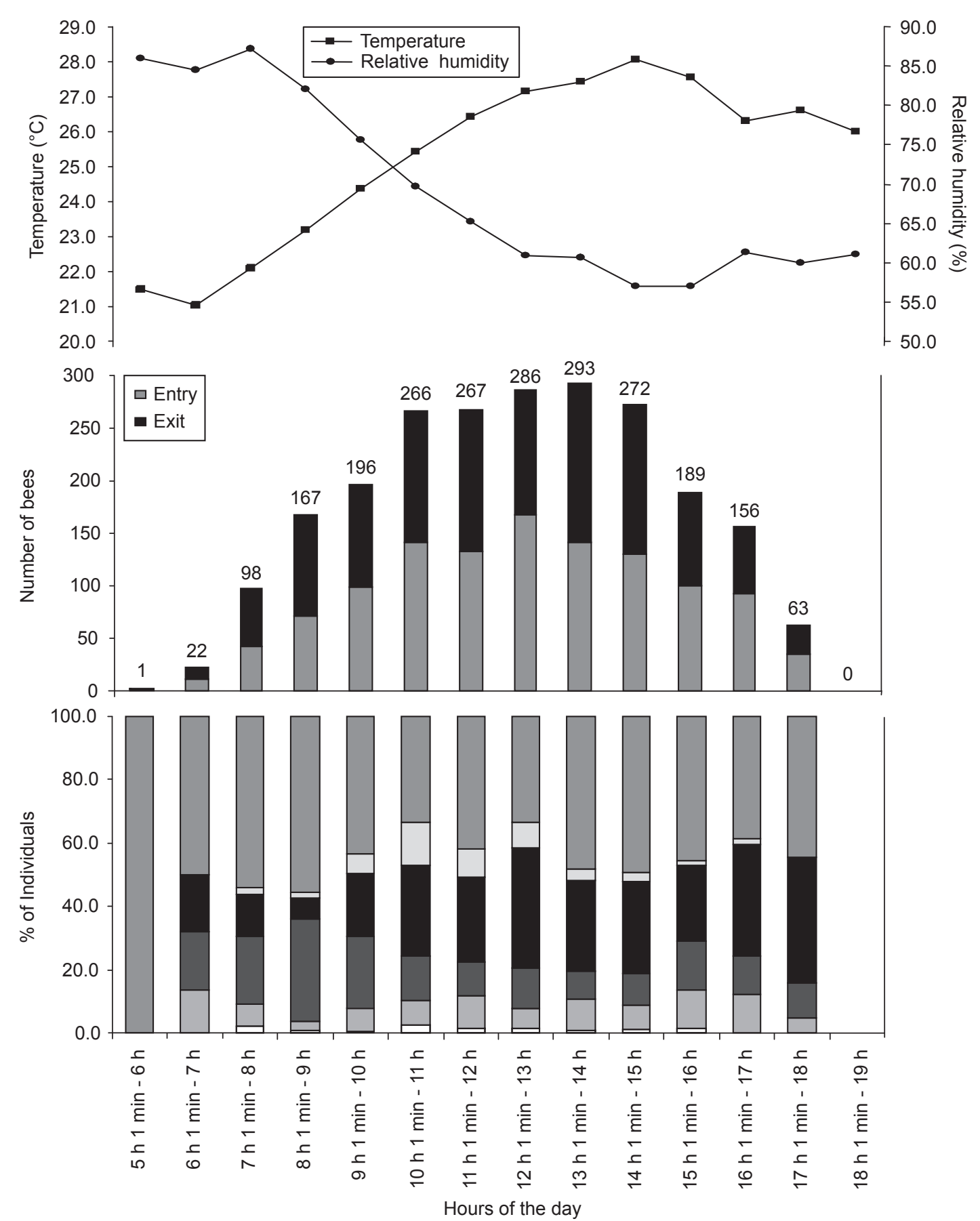

\begin{tabular}{|c|c|c|c|c|c|}
\hline$\square$ Resin & $\square$ Mud & $\square$ Pollen & - Wal & $\square$ Debris & $\square$ Free of Load \\
\hline \multicolumn{4}{|c|}{ Entry } & \multicolumn{2}{|r|}{ Exit } \\
\hline
\end{tabular}

Fig. 2 - Temperature and relative humidity variation in Santa Terezinha-BA, hourly traffic of Melipona asilvai foragers and flight activity and transported material distribution: June/2002 to March/2003. (WAL = bee without apparent load). 
might still occur in the late afternoon. Generally, M. asilvai also collected more pollen in the morning following the tendency suggested by this author.

In general, it was observed that temperature and relative humidity influenced the collection of food and nest building materials by $M$. asilvai.

\section{REFERENCES}

BIESMEIJER, J. C., BORN, M., LUKÁCS, S. \& SOMMEIJER, M. J., 1999, The response of the stingless bee Melipona beecheii to experimental pollen stress, worker loss and different levels of information input. J. Apicult. Res., 38: 33-41.

BRUENING, H., 1990, Abelha jandaíra. Coleção Mossoroense, série $\mathrm{C}$, volume 557, 181p.

CARVAlHO, C. A. L. de, 1999, Diversidade de abelhas (Hymenoptera, Apoidea) e plantas visitadas no município de Castro Alves-BA. Tese de Doutorado em Ciências, Escola Superior de Agricultura "Luiz de Queiroz", Universidade de São Paulo, Piracicaba-SP, 104p.

CARVALHO, C. A. L. de \& MARCHINI, L. C., 1999, Tipos polínicos coletados por Nannotrigona testaceicornis e Tetragonisca angustula (Hymenoptera, Apidae, Meliponinae. Sci. Agri. 56: 717-722.

CARVALHO, C. A. L. de, MARCHINI, L. C. \& ROS, P. B., 1999, Fontes de pólen utilizadas por Apis mellifera L. e algumas espécies de Trigonini (Apidae) em Piracicaba (SP). Bragantia, 58: 49-56.

GUIBU, L. S., RAMALHO, M., KLEINERT-GIOVANNINI, A. \& IMPERATRIZ-FONSECA, V. L., 1988, Exploração dos recursos florais por colônias de Melipona quadrifasciata (Apidae, Meliponinae). Rev. Bras. Biol., 48: 299-305.

HILÁRIO, S. D., IMPERATRIZ-FONSECA， V. L. \& KLEINERT, A. de M. P., 2000, Flight activity and colony strength in the stingless bee Melipona bicolor bicolor (Apidae, Meliponinae). Rev. Bras. Biol., 60: 299-306.
HILÁRIO, S. D., IMPERATRIZ-FONSECA, V. L., KLEINERT, A. de M. P., 2001, Responses to climatic factors by foragers of Plebeia pugnax Moure (in litt.) (Apidae, Meliponinae). Rev. Bras. Biol., 61: 191-196.

IWAMA, S. A., 1977, Influência de fatores climáticos na atividade externa de Tetragonisca angustula (Apidae, Meliponinae). Bol. Zool., 2:189-201.

KERR, W. E., 1996, Biologia e manejo da tiuba: a abelha do Maranhão. São Luis: EDUFMA, 156p.

KERR, W. E., CARVALHO, G. A. \& NASCIMENTO, V. A., 1996, Abelha uruçu: biologia, manejo e conservação. Belo Horizonte: Acangaú, 144p.

LORENZON, M. C. A., MATRANGOLO, C. A. R. \& SCHOEREDER, J. H., 2003, Flora visitada pelas abelhas eussociais (Hymenoptera, Apidae) na Serra da Capivara, em Caatinga do Sul do Piauí. Neotrop. Entomol., 32: 27-36.

MOUGA, D. M. D. S., 1984, Atividade externa de Paratrigona subnuda (Hymenoptera, Apidae, Meliponinae). Cien. Cult., 36: 596-597.

PEDRO, S. R. DE M. \& CAMARGO, J. M. F. de, 1991, Interactions on floral resources between the africanized honey bee Apis mellifera $\mathrm{L}$. and the native bee comunity (Hymenoptera: Apoidea) in a natural "cerrado" ecosystem in southeast Brazil. Apidologie, 22: 397-415.

PIERROT, L. M. \& SCHLINDWEIN, C., 2003, Variation in dialy flight activity and foraging patterns in colonies of uruçu-Melipona scutellaris Latreille (Apidae, Meliponini). Rev. Bras. Zool., 20: 565-571.

RAMALHO, M., KLEINERT-GIOVANNINI, A. \& IMPERATRIZ-FONSECA, V. L., 1989, Utilization of floral resources by species of Melipona (Apidae, Meliponinae): floral preferences. Apidologie, 20: 185-195.

ROUBIK, D. W., 1989, Ecology and natural history of tropical bees. Cambridge Tropical Biology Series, 514p.

ZANELLA, F. C. V., 2000, The bees of the Caatinga (Hymenoptera, Apoidea, Apiformes): a species list and comparative notes regarding their distribution. Apidologie, 31: $579-592$. 